\section{Kidney \\ Blood Pressure Research}

Kidney Blood Press Res 2013;37:259-268

DOI: 10.1159/000350151

Published onlıne: July ZZ, 2013

(C) 2013 S. Karger AG, Basel

www.karger.com/kbr

$1423-0143 / 13 / 0375-0259 \$ 38.00 / 0$

\title{
Effect of Conversion from ESA with Shorter Half-Life to CERA Once Monthly for Maintaining Hb Concentration in Pre- Dialysis CKD Patients
}

\author{
Ji-Young Choi ${ }^{a}$ Chul Woo Yang ${ }^{b}$ Yeong-Hoon Kim ${ }^{c} \quad$ Kwon Wook Joo ${ }^{d}$ \\ Tae-Hyun Yoo ${ }^{e}$ Kang Wook Lee ${ }^{f}$ Sang-Ho Lee ${ }^{g}$ Ju-Young Moong \\ Sug Kyun Shin ${ }^{\text {h Wooseong Huh }}{ }^{\mathrm{i}}$ Nam-Ho Kim ${ }^{j}$ Sun-Hee Park ${ }^{\mathrm{a}}$ \\ Chan-Duck Kim ${ }^{\mathrm{a}}$ Yong-Lim Kim ${ }^{\mathrm{a}}$
}

\begin{abstract}
aDepartment of Internal Medicine, Kyungpook National University School of Medicine; bepartment

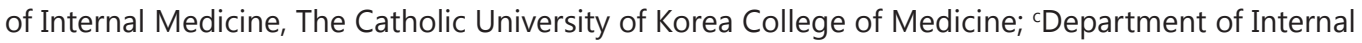
Medicine, Inje University College of Medicine; ${ }^{d}$ Department of Internal Medicine, Seoul National

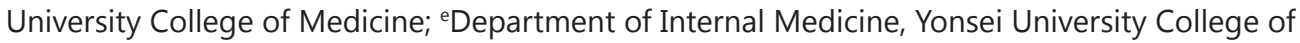
Medicine; fDepartment of Internal Medicine, Chungnam National University College of Medicine;

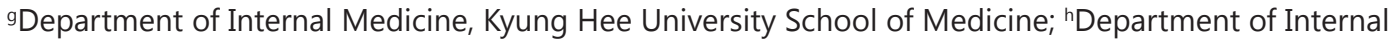
Medicine, National health insurance corporation Ilsan Hospital; 'Department of Internal Medicine, Samsung Medical Center, Sungkyunkwan University School of Medicine; 'Department of Internal Medicine, Chonnam National University Medical School
\end{abstract}

\section{Key Words}

Hemoglobin • Erythropoietin • Chronic kidney disease • Biomarker

\begin{abstract}
Background: The purpose of this study is to identify whether hemoglobin $(\mathrm{Hb})$ concentrations can be maintained, and to investigate changes in biomarkers, when switching from erythropoietin stimulating agents (ESA) with shorter half-life to once-monthly subcutaneous methoxy polyethylene glycol-epoetin $\beta$ (CERA) in pre-dialysis chronic kidney disease (CKD) patients. Methods: Pre-dialysis CKD patients $(n=191)$ aged $\geq 18$ years who maintained their $\mathrm{Hb}$ level $10-12 \mathrm{~g} / \mathrm{dL}$ through use of epoetin- $\alpha$, epoetin- $\beta$, or darbepoetin- $\alpha$ were enrolled. $\mathrm{Hb}$ levels and CERA dose was assessed prospectively for 24 weeks. Serum biomarkers related to coagulation, endothelial function, and iron metabolism were measured at weeks 0 and 24. Results: Baseline $\mathrm{Hb}$ concentration was $10.8 \pm 0.6 \mathrm{~g} / \mathrm{dL}$. Twelve and 24 weeks after conversion, mean $\mathrm{Hb}$ levels were $11.9 \pm 0.9$ and $11.2 \pm 0.9 \mathrm{~g} / \mathrm{dL}$, respectively. The mean monthly CERA dose required to maintain $\mathrm{Hb}$ levels was gradually reduced. Of total 387 dose adjustments, dose increases and decreases occurred in 35 (9.0\%) and 352 (91.0\%) episodes, respectively. $\mathrm{Hb}$ overshoot occurred in 14 (9.7\%) patients. P-selectin was significantly decreased, whereas VCAM was significantly increased 24 weeks after conversion $(P<0.05)$. Serum soluble transferrin receptor, E-selectin, and prohepcidin levels were similar before and after switching
\end{abstract}




\section{Kidney \\ Blood Pressure Research}

Kidney Blood Press Res 2013;37:259-268

\begin{tabular}{l|l}
\hline DOI: $10.1159 / 000350151$ & C 2013 S. Karger AG, Basel
\end{tabular}

www.karger.com/kbr

Choi/Yang/Kim/Joo/Yoo/Lee/Lee/Moon/Shin/Huh/Kim/Park/Kim/Kim: Effect of

Conversion from ESA with Shorter Half-Life to CERA in Pre-Dialysis CKD Patients

to CERA $(P=\mathrm{N}-\mathrm{S})$. Conclusion: Conversion from ESA with shorter half-life to subcutaneous once-monthly CERA in pre-dialysis CKD patients can efficaciously maintain $\mathrm{Hb}$. The CERA dose requirement decreased significantly. The conversion ratio may need to be reduced when switching from ESA with shorter half-life to CERA. CERA may change biomarkers associated with platelet reactivity and endothelial microenvironment.

Copyright (C) 2013 S. Karger AG, Basel

\section{Introduction}

Renal anemia is a common complication of chronic kidney disease (CKD), which can result from impaired erythropoietin (EPO) production. Anemia contributes to cardiovascular complications, increased mortality, and poor quality of life for CKD patients [1,2]. Many CKD patients may require treatment with erythropoiesis stimulating agents (ESA) to maintain stable correction of their hemoglobin $(\mathrm{Hb})$ levels. Commercially-available ESA with short half-lives such as epoetin- $\alpha$ or epoetin- $\beta$ (2 3 times per week) and darbepoetin- $\alpha$ (weekly) require relatively frequent injections. Recently, subcutaneous methoxy polyethylene glycolepoetin $\beta$ (continuous erythropoietin receptor activator, CERA) was suggested as a oncemonthly injection due to its significantly longer elimination half-life that allows for a further extension of dosing intervals. So far, several studies have established that CERA successfully maintained target $\mathrm{Hb}$ after conversion from other ESA [3-6]. There is also a report that CERA improved quality of life in CKD patients by reducing the frequency of ESA injections as well as conveniently managing anemia, especially in the outpatient clinic [7].

Thrombosis is one of the side effects of ESA used to treat anemia in CKD patients. ESA affects thrombopoiesis and platelet function. Erythropoietin markedly enhances endothelial activation and platelet reactivity, which may adversely affect patients at cardiovascular risk [8]. However, there has been no study that compared levels of biomarkers related to platelet activity, endothelial function, and iron metabolism among the types of ESA used in patients with CKD.

In the OASIS (Once-monthly Administration of Subcutaneous CERA for the maIntenance of hemoglobin levels in patients with chronic renal anaemia who are not on dialysiS) study, a single arm, open-label study to assess the efficacy, safety and tolerability of CERA, we assessed whether or not $\mathrm{Hb}$ concentrations can be maintained when switching from ESA with shorter half-life to once monthly CERA. Simultaneously, levels of biomarkers associated with coagulation, endothelial function, and iron metabolism according to conversion from ESA with shorter half-life to CERA in pre-dialysis CKD patients were investigated.

\section{Materials and Methods}

\section{Patients}

Patients aged $\geq 18$ years with a glomerular filtration rate (GFR) $\geq 10 \mathrm{~mL} / \mathrm{min} / 1.73 \mathrm{~m}^{2}$ by the Modification of Diet in Renal Disease (MDRD) equation, who were not on dialysis, were screened at 10 centers in Korea. They were required to have received treatment with ESA with shorter half-life (epoetin- $\alpha$, epoetin- $\beta$, or darbepoetin- $\alpha$ ) subcutaneously with the same dosing interval during the previous month, and have had no change in total weekly dose. They were also required to maintain $\mathrm{Hb}$ concentrations between 10.0 and $12.0 \mathrm{~g} / \mathrm{dL}$ and show adequate iron status with serum ferritin $>100 \mathrm{ng} / \mathrm{mL}$ or transferrin saturation (TSAT) $>20 \%$ or hypochromic red cells $<10 \%$ at screening $(-4$ weeks).

Patients with poorly controlled hypertension, significant acute or chronic bleeding such as overt gastrointestinal bleeding within 8 weeks before screening or during the stability verification period, had a history of red blood cell transfusion during the previous 2 months, active malignancy or infection, hemolysis, folic acid or vitamin B12 deficiency, and pure red cell aplasia were excluded. Patients who had congestive heart failure (NYHA class IV), myocardial infarction, stroke, severe or unstable coronary artery disease, severe liver disease during the previous 3 months, or a history of previous CERA administration were also excluded. 


\section{Kidney Blood Pressure Research}

Fig. 1. StudyDesign.

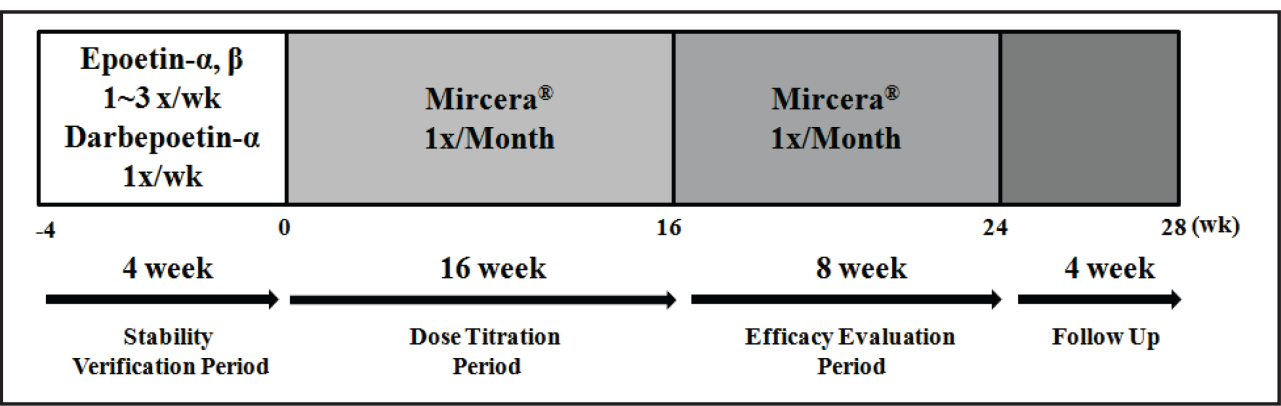

Table 1. Dose adjustment of CERA

\begin{tabular}{|c|c|}
\hline Cause of dose adjustment & Adjusted dosage \\
\hline A single $\mathrm{Hb} \leq 9.0 \mathrm{~g} / \mathrm{dL}$ & $50 \%$ increase \\
\hline $\begin{array}{l}\text { Difference between } 2 \text { consecutive } \mathrm{Hb} \text { indicates } \geq \\
2.0 \mathrm{~g} / \mathrm{dL} \text { decrease }\end{array}$ & $50 \%$ increase \\
\hline $\begin{array}{l}\text { Two consecutive values }<10.5 \mathrm{~g} / \mathrm{dL} \text { and }>9.0 \mathrm{~g} / \mathrm{dL} \\
\text { and deviation from reference value is }>1.0 \mathrm{~g} / \mathrm{dL}\end{array}$ & $25 \%$ increase \\
\hline Two consecutive values $<10.0 \mathrm{~g} / \mathrm{dL}$ & $25 \%$ increase \\
\hline A single $\mathrm{Hb} \geq 13.0 \mathrm{~g} / \mathrm{dL}$ & $\begin{array}{l}\text { Hold CERA administration until } \mathrm{Hb} \\
\text { falls below } 12.0 \mathrm{~g} / \mathrm{dL} \text { then restart } \\
\text { treatment at } 50 \% \text { of previous dose }\end{array}$ \\
\hline $\begin{array}{l}\text { Difference between } 2 \text { consecutive } \mathrm{Hb} \text { indicates } \geq \\
2.0 \mathrm{~g} / \mathrm{dL} \text { increase }\end{array}$ & $50 \%$ decrease \\
\hline $\begin{array}{l}\text { Single values }>11.5 \mathrm{~g} / \mathrm{dL} \text { and }<13.0 \mathrm{~g} / \mathrm{dL} \text { and } \\
\text { deviation from reference value is }>1.0 \mathrm{~g} / \mathrm{dL}\end{array}$ & $25 \%$ decrease \\
\hline A single $\mathrm{Hb}>12.0 \mathrm{~g} / \mathrm{dL}$ & $25 \%$ decrease \\
\hline
\end{tabular}

Ethical approval was obtained from the Institutional Review Board at each center and all participants in this study provided written informed consent.

\section{Study Design}

This study is a single-arm, open-label, multi-center study to assess $\mathrm{Hb}$ maintenance with oncemonthly subcutaneous CERA therapy in pre-dialysis patients with chronic renal anemia. The study design is shown in Figure 1 . Hb values were assessed during the stability verification period $(-4,-2$, and 0 weeks). Patients whose mean $\mathrm{Hb}$ values were not between $10.0 \mathrm{~g} / \mathrm{dL}$ and $12.0 \mathrm{~g} / \mathrm{dL}$ were withdrawn. The dosing frequency and the total weekly dose of ESA treatments prior to conversion were maintained through the stability verification period. Epoetin- $\alpha$, epoetin- $\beta$, or darbepoetin- $\alpha$ was switched to subcutaneous oncemonthly CERA. Subcutaneous CERA (Mircera ${ }^{\circledR}$, Roche) was administered at week 0 to patients whose mean $\mathrm{Hb}$ values were between $10.0 \mathrm{~g} / \mathrm{dL}$ and $12.0 \mathrm{~g} / \mathrm{dL}$.

The initial dose of CERA for each patient was based on the last dose of previously administered ESA in the week preceding the switch to CERA. Patients treated with receiving up to either darbepoetin- $\alpha 40 \mu \mathrm{g} /$ week or epoetin- $\alpha$ or epoetin- $\beta$ 8,000 IU/week received CERA $120 \mu \mathrm{g} / \mathrm{month}$.

CERA was administered every 4 weeks for 24 weeks, including a 16-week dose titration period, followed by an 8-week efficacy evaluation period. The dose of CERA was adjusted to maintain the target $\mathrm{Hb}$ range throughout the dose titration and efficacy evaluation periods (weeks 1 to 24). The target $\mathrm{Hb}$ range was defined as the individual patient's $\mathrm{Hb}$ within a range of $\pm 1.0 \mathrm{~g} / \mathrm{dL}$ of the reference $\mathrm{Hb}$ concentration and between 10.0 and $12.0 \mathrm{~g} / \mathrm{dL}$. The reference $\mathrm{Hb}$ was taken as the mean of all $\mathrm{Hb}$ assessments during the stability verification period. CERA dose adjustments were performed as Table 1.

Patients whose mean amplitude of upward $\mathrm{Hb}$ excursion was $>3.0 \mathrm{~g} / \mathrm{dL}$ were defined as the $\mathrm{Hb}$ overshoot group. 


\section{Kidney Blood Pressure Research}

Kidney Blood Press Res 2013;37:259-268

DOI: $10.1159 / 000350151$

Publisned ontıne: July ZZ, 2013

(C) 2013 S. Karger AG, Basel

www.karger.com/kbr

Choi/Yang/Kim/Joo/Yoo/Lee/Lee/Moon/Shin/Huh/Kim/Park/Kim/Kim: Effect of Conversion from ESA with Shorter Half-Life to CERA in Pre-Dialysis CKD Patients
Assessment

Blood pressure, heart rate, $\mathrm{Hb}$, and hematocrit level was assessed every 4 weeks for 24 weeks. White blood cell counts, platelet counts, mean corpuscular volume, serum creatinine, albumin, C-reactive protein (CRP), potassium, phosphate, and iron parameters (including serum iron, ferritin, transferrin or total iron-binding capacity, and transferrin saturation) were additionally assessed at weeks 8, 16, 20, and 24 .

A $2 \mathrm{~mL}$ serum sample for biomarker research was obtained at the treatment initiation visit (week 0 ) and on the final study visit (week 24). The serum samples were immediately stored at or below -80 ${ }^{\circ} \mathrm{C}$ until use. Serum concentrations of soluble transferrin receptor (sTfR), E-selectin, P-selectin, and vascular cell adhesion molecule (VCAM) were measured using commercial enzyme immunoassay kits (R\&D Systems, Minneapolis, MN) as instructed by the manufacturer. Serum prohepcidin concentrations were also determined using an enzyme-linked immunosorbent assay (ELISA), hepcidin prohormone ELISA kit (DRG Instruments, Marburg, Germany) according to the manufacturer's instructions. This kit was based on antibodies specific for amino acids 28-47 of the pro-region of prohepcidin. A standard curve was produced prior to every measurement with the peptides supplied in the kit. All serum samples were measured in duplicate, and the average values were adopted.

\section{Statistical Analyses}

Demographic data were expressed as the mean \pm standard deviation (SD) and analyzed using the student t-test and chi-square test, or Fischer's exact test, using SPSS software (SPSS version 14.0, Chicago, IL, USA). Changes in serum biomarkers between weeks 0 and 24 in the overall group and the non-overshoot group were compared with paired t-test. Changes in serum biomarkers in the overshoot group were compared with the Wilcoxon signed rank test because of the small number of patients in this group.

The efficacy of CERA was analyzed based on the per protocol (PP) subjects, whereas appropriate confirmatory analyses were conducted in the intention-to-treat (ITT) subjects. The PP subjects were defined as all patients with $>2$ recorded Hb values during weeks 16-24, no missing administrations of CERA during weeks 16-24, and adequate iron status defined as mean serum ferritin $\geq 100 \mathrm{ng} / \mathrm{mL}$ and mean TSAT $\geq 20 \%$ during weeks 16-24. Statistical significance was determined as a $P$ value less than 0.05 .

\section{Results}

\section{Study population}

One hundred ninety-one patients were enrolled in this study and 187 patients received at least 1 dose of CERA. Of the 191 patients, 30 patients did not maintain adequate iron status during the study period, 15 patients dropped out before the end of the efficacy evaluation period because of withdrawal of informed consent or transfusion or concurrent illness etc.,

\begin{tabular}{ll}
\hline Gender (Male / Female) & $61(42.1 \%) / 84(57.9 \%)$ \\
Body Weight $(\mathrm{kg})$ & $60.5 \pm 10.0$ \\
BMI $\left(\mathrm{kg} / \mathrm{m}^{2}\right)$ & $23.6 \pm 3.4$ \\
Comorbidities & \\
$\quad$ Diabetes & $80(55.2 \%)$ \\
$\quad$ Hypertension & $108(74.5 \%)$ \\
$\quad$ Ischemic heart disease & $18(12.4 \%)$ \\
$\quad$ Cerebral vascular disease & $6(4.1 \%)$ \\
$\quad$ Venous thrombosis & $1(0.7 \%)$ \\
$\quad$ Congestive heart failure & $6(4.1 \%)$ \\
GFR (ml/min/1.73 m $\left.{ }^{2}\right)$ & $19.9 \pm 8.5$ \\
ACEi medication & $3(2.1 \%)$ \\
ARB medication & $112(77.2 \%)$ \\
ACEi and ARB medication & $9(6.2 \%)$ \\
Iron agents & $137(77.2 \%)$ \\
$\quad$ Intravenous iron sucrose & $2(1.5 \%)$ \\
$\quad$ Oral ferrous sulfate & $133(91.7 \%)$ \\
Hemoglobin (g/dL) & $10.8 \pm 0.7$ \\
Ferritin ( $\mu$ g $/ \mathrm{L})$ & $245.8 \pm 210.5$ \\
Transferrin Saturation (\%) & $32.7 \pm 12.1$ \\
Previous other ESA before switching & $69(47.6 \%) / 76(52.4 \%)$ \\
(Epoetin- $\alpha, \beta /$ Darbepoetin- $\alpha)$ & \\
\hline BMI, body mass index; GFR, glomerular filtration rate; ACEi, \\
angiotensin converting enzyme inhibitor; ARB, angiotensin- \\
receptor blocker. & \\
\hline
\end{tabular}




\section{Kidney Blood Pressure Research}

Fig. 2. Hb level and dose of CERA at each visit in per protocol subjects. Data expression; $\mathrm{Hb}$ : M e a \pm S. D ., CERA dose: Mean \pm S.E.

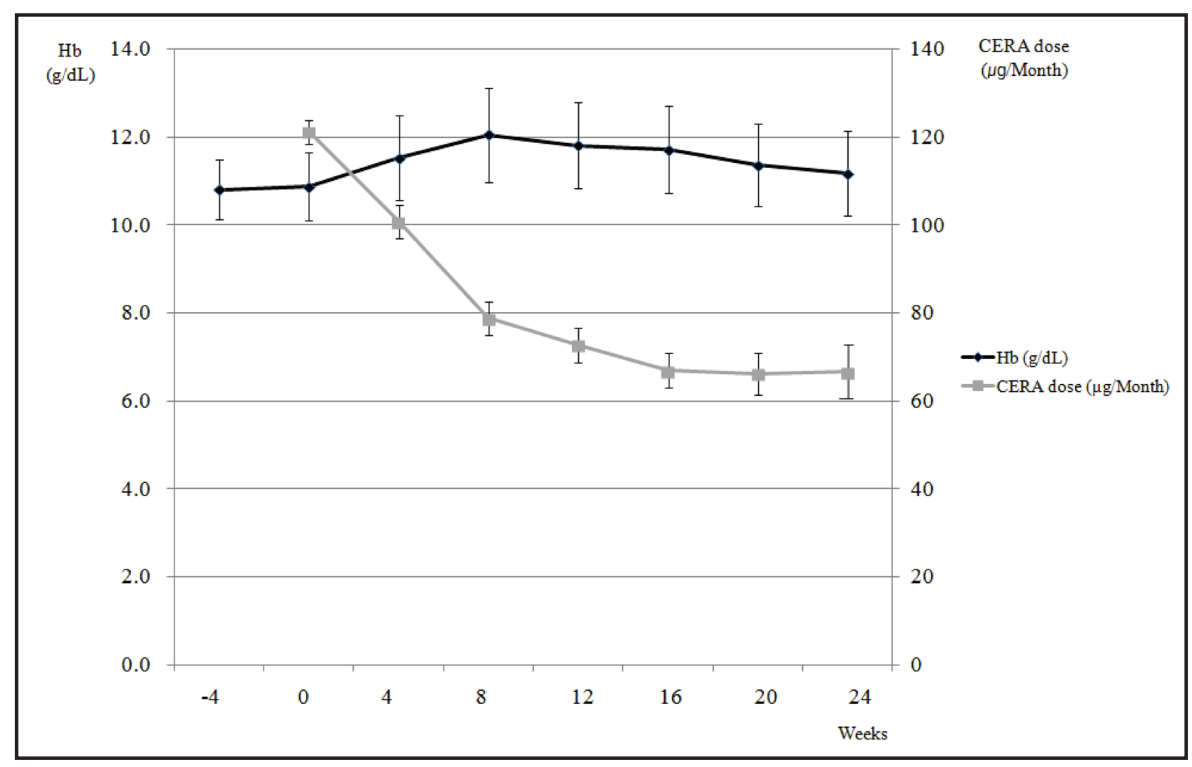

and 1 patient missed a CERA administration. Finally, 145 patients were satisfied the criteria for the PP analyses. Baseline characteristics of PP subjects are presented in Table 2.

Of 145 patients, $80(55.2 \%)$ had diabetes, $18(12.4 \%)$ had ischemic heart disease, and $6(4.1 \%)$ patients had cerebro-vascular disease. Angiotensin converting enzyme inhibitor alone was administered to $3(2.1 \%)$ patients, and angiotensin II receptor blocker alone to 112 $(77.2 \%)$ patients. Nine $(6.2 \%)$ patients took both angiotensin converting enzyme inhibitor and angiotensin II receptor blockers. Concomitant iron agents were administered to 137 $(77.2 \%)$ patients during the study period. The most common agent for iron supplement was oral ferrous sulfate in $133(91.7 \%)$ patients followed by intravenous iron sucrose in $2(1.5 \%)$ patients. Mean baseline serum ferritin and transferrin saturations were $245.8 \pm 210.5 \mu \mathrm{g} / \mathrm{L}$ and $32.7 \pm 12.1 \%$, respectively. Before ESAs switching, 69 (47.6\%) patients had used epoetin- $\alpha$ or epoetin- $\beta$ and 76 (52.4\%) patients had used darbepoetin- $\alpha$.

\section{Efficacy}

One hundred twenty-one (83.4\%) of the 145 PP subjects had $\mathrm{Hb}$ levels between $10.0 \mathrm{~g} / \mathrm{dL}$ and $12.0 \mathrm{~g} / \mathrm{dL}$ at week 0 . In all patients, ESA with shorter half-life were switched to CERA $120 \mu \mathrm{g} / \mathrm{month}$ at week 0 because all had been treated with either less than epoetin- $\alpha$ or epoetin- $\beta(n=69) 8,000 \mathrm{IU} /$ week or darbepoetin- $\alpha(n=76) 40 \mu \mathrm{g} /$ week during the stability verification period. Eighty four (57.9\%) and $108(74.5 \%)$ patients had Hb levels within the target range and between $10.0 \mathrm{~g} / \mathrm{dL}$ and $12.0 \mathrm{~g} / \mathrm{dL}$, respectively, during the efficacy evaluation period (16 24 weeks). The mean $\mathrm{Hb}$ level of PP subjects was $11.3 \pm 0.8 \mathrm{~g} / \mathrm{dL}$ during the efficacy evaluation period. Mean Hb levels and doses of CERA administered at each visit are represented in Figure 2. Hb levels were stably maintained, and the doses of CERA for maintaining target $\mathrm{Hb}$ levels were gradually reduced. CERA dose adjustments and the reason for the dose adjustments are shown in Table 3. A total of 387 episodes of dose adjustments occurred. There were 35 (9.0\%) episodes of dose increases and 352 (91.0\%) episodes of dose decreases during the study period.

$\mathrm{Hb}$ overshoot occurred in $14(9.7 \%)$ patients. There was no significant difference in the type of ESA with shorter half-life before switching and usage of iron agents between the overshoot and non-overshoot groups.

Biomarkers

Serum biomarkers in the PP subjects in each group at weeks 0 and 24 are shown in Table 4. sTfR, E-selectin, and prohepcidin showed no significant differences before and after 


\section{Kidney \\ Blood Pressure Research}

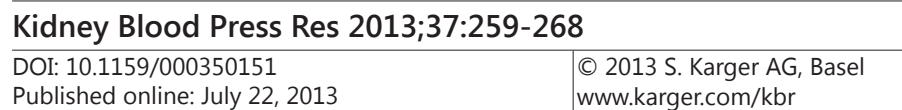

Choi/Yang/Kim/Joo/Yoo/Lee/Lee/Moon/Shin/Huh/Kim/Park/Kim/Kim: Effect of Conversion from ESA with Shorter Half-Life to CERA in Pre-Dialysis CKD Patients

Table 3. CERA dose adjustment according to the guidelines and reason for the dose adjustment (PP analyses).

\begin{tabular}{|c|c|c|c|c|}
\hline & $\begin{array}{l}\text { Adjusted } \\
\text { dosage }\end{array}$ & Cause of dose adjustment & $\begin{array}{l}\text { Episodes No. } \\
\text { (\% of } 387 \text { dose } \\
\text { adjustments) }\end{array}$ & $\begin{array}{l}\text { Episodes/ } \\
\text { Patient }\end{array}$ \\
\hline \multirow{4}{*}{ Increase } & $50 \%$ & A single $\mathrm{Hb} \leq 9.0 \mathrm{~g} / \mathrm{dL}$ & $4(1.0 \%)$ & 0.028 \\
\hline & $50 \%$ & Difference between 2 consecutive $\mathrm{Hb}$ indicates $\geq 2.0 \mathrm{~g} / \mathrm{dL}$ decrease & $1(0.3 \%)$ & 0.007 \\
\hline & $25 \%$ & $\begin{array}{l}\text { Two consecutive values }<10.5 \mathrm{~g} / \mathrm{dL} \text { and }>9.0 \mathrm{~g} / \mathrm{dL} \text { and deviation } \\
\text { from reference value is }>1.0 \mathrm{~g} / \mathrm{dL}\end{array}$ & $25(6.5 \%)$ & 0.173 \\
\hline & $25 \%$ & Two consecutive values $<10.0 \mathrm{~g} / \mathrm{dL}$ & $5(1.3 \%)$ & 0.035 \\
\hline \multirow{4}{*}{ Decrease } & Hold $^{\mathrm{a}}$ & A single $\mathrm{Hb} \geq 13.0 \mathrm{~g} / \mathrm{dL}$ & $111(28.7 \%)$ & 0.766 \\
\hline & $50 \%$ & Difference between 2 consecutive $\mathrm{Hb}$ indicates $\geq 2.0 \mathrm{~g} / \mathrm{dL}$ increase & $1(0.3 \%)$ & 0.007 \\
\hline & $25 \%$ & $\begin{array}{l}\text { Single values }>11.5 \mathrm{~g} / \mathrm{dL} \text { and }<13.0 \mathrm{~g} / \mathrm{dL} \text { and deviation } \\
\text { from reference value is }>1.0 \mathrm{~g} / \mathrm{dL}\end{array}$ & $212(54.8 \%)$ & 1.463 \\
\hline & $25 \%$ & A single $\mathrm{Hb}>12.0 \mathrm{~g} / \mathrm{dL}$ & $28(7.2 \%)$ & 0.193 \\
\hline
\end{tabular}

Table 4. Serum biomarkers in each group of the PP subjects $(\mathrm{n}=145)$ at weeks 0 and 24

\begin{tabular}{lcccc}
\hline Biomarker & Group & Week 0 & Weeks 24 & $p$ value \\
\hline \multirow{2}{*}{ sTfR } & Total & $20.1 \pm 7.3$ & $19.1 \pm 7.1$ & 0.08 \\
$(\mathrm{nmol} / \mathrm{L})$ & Overshoot & $19.1 \pm 6.0$ & $17.9 \pm 4.4$ & 0.59 \\
& Non-overshoot & $20.2 \pm 7.4$ & $19.2 \pm 7.4$ & 0.10 \\
\hline \multirow{2}{*}{ E-selectin } & Total & $37.0 \pm 15.3$ & $36.0 \pm 15.7$ & 0.36 \\
$(\mathrm{ng} / \mathrm{mL})$ & Overshoot & $34.1 \pm 14.5$ & $38.8 \pm 14.0$ & 0.24 \\
& Non-overshoot & $37.3 \pm 15.4$ & $35.7 \pm 15.9$ & 0.19 \\
\hline \multirow{2}{*}{ P-selectin } & Total & $88.6 \pm 113.2$ & $60.7 \pm 61.7$ & $0.03^{\mathrm{a}}$ \\
$(\mathrm{ng} / \mathrm{mL})$ & Overshoot & $62.4 \pm 35.9$ & $65.6 \pm 46.5$ & 0.95 \\
& Non-overshoot & $91.2 \pm 118.1$ & $60.2 \pm 63.2$ & $0.03^{\mathrm{a}}$ \\
\hline \multirow{2}{*}{ VCAM } & Total & $1493.9 \pm 487.6$ & $1606.9 \pm 574.3$ & $0.001^{\mathrm{a}}$ \\
$(\mathrm{ng} / \mathrm{mL})$ & Overshoot & $1539.8 \pm 439.9$ & $1726.4 \pm 609.1$ & 0.07 \\
& Non-overshoot & $1489.2 \pm 493.5$ & $1594.6 \pm 571.7$ & $0.006^{\mathrm{a}}$ \\
\hline \multirow{2}{*}{ Prohepcidin } & Total & $233.7 \pm 70.0$ & $227.7 \pm 66.8$ & 0.43 \\
$(\mathrm{ng} / \mathrm{mL})$ & Overshoot & $237.3 \pm 50.5$ & $218.3 \pm 41.3$ & 0.18 \\
& Non-overshoot & $233.3 \pm 71.8$ & $228.6 \pm 68.7$ & 0.67 \\
\hline \multirow{2}{*}{ Ferritin } & Total & $250.4 \pm 212.7$ & $314.6 \pm 194.0$ & $<0.001^{\mathrm{a}}$ \\
$(\mathrm{ng} / \mathrm{mL})$ & Overshoot & $243.7 \pm 114.8$ & $292.3 \pm 123.2$ & 0.42 \\
\hline \multirow{2}{*}{ Tsat $(\%)$} & Non-overshoot & $251.1 \pm 220.6$ & $316.9 \pm 200.0$ & $<0.001^{\mathrm{a}}$ \\
\hline & Total & $32.9 \pm 12.2$ & $41.0 \pm 13.8$ & $<0.001^{\mathrm{a}}$ \\
& Overshoot & $33.1 \pm 13.2$ & $45.6 \pm 14.2$ & $0.01^{\mathrm{a}}$ \\
& Non-overshoot & $32.9 \pm 12.2$ & $40.6 \pm 13.8$ & $<0.001^{\mathrm{a}}$ \\
\hline
\end{tabular}

sTfR, soluble transferrin receptor; VCAM, vascular cell adhesion molecule; Tsat, transferrin saturation. $P$ value: paired t-test between 0 and 24 weeks in each group; ${ }^{a} P$-value $<0.05$

switching from ESA with shorter half-life to CERA in either the overshoot or non-overshoot groups. P-selectin did not change before or after switching to CERA in the overshoot group. However, it was significantly decreased at week 24 after switching from ESA with shorter halflife to CERA in the non-overshoot group $(P=0.03)$. Although VCAM had a tendency to increase at week 24 after switching compared with week 0 in the overshoot group, the difference was not statistically significant $(P=0.07)$. However, VCAM was significantly increased at week 24 after switching to CERA compared with week 0 in the non-overshoot group $(P=0.006)$. Serum ferritin levels were not significantly different before or after switching of the type of ESA in the overshoot group, whereas it was significantly increased at week 24 after switching compared with week 0 in the non-overshoot group $(P<0.001)$. Transferrin saturation was significantly increased at week 24 compared with week 0 in both the overshoot $(P=0.01)$ and non-overshoot groups $(P<0.001)$. 


\section{Kidney Blood Pressure Research}

\section{Kidney Blood Press Res 2013;37:259-268}

DOI: 10.1159/000350151

Published onlıne: July 22, 2013

(C) 2013 S. Karger AG, Basel

www.karger.com/kbr

Choi/Yang/Kim/Joo/Yoo/Lee/Lee/Moon/Shin/Huh/Kim/Park/Kim/Kim: Effect of Conversion from ESA with Shorter Half-Life to CERA in Pre-Dialysis CKD Patients

Table 5. Adverse events

\begin{tabular}{lcc}
\hline & $\begin{array}{c}\text { Patients } n \\
\text { (\% of 191 patients) }\end{array}$ & Events $n$ \\
\hline Any adverse events & $141(73.8 \%)$ & 357 \\
Serious adverse events & $30(15.7 \%)$ & 38 \\
Adverse events leading to withdrawal & $5(2.6 \%)$ & 7 \\
\hline Upper respiratory tract infection & $21(11.0 \%)$ & 23 \\
Nasopharyngitis & $17(8.9 \%)$ & 21 \\
Hypertension & $15(7.9 \%)$ & 16 \\
Initiation of dialysis & $10(5.2 \%)$ & 10 \\
Headache & $9(4.7 \%)$ & 9 \\
Diarrhea & $5(2.6 \%)$ & 5 \\
Arteriovenous fistula complication & $2(1.0 \%)$ & 2 \\
Ischemic cardiomyopathy & $1(0.5 \%)$ & 1 \\
Cerebral infarction & $1(0.5 \%)$ & 1 \\
Sepsis & $1(0.5 \%)$ & 1 \\
Pneumonia & $1(0.5 \%)$ & 1 \\
Muscle spasms & $1(0.5 \%)$ & 1 \\
Deaths & $1(0.5 \%)$ & 1 \\
\hline
\end{tabular}

Safety

Any and serious adverse events (SAE) were presented in Table 5. In total, 357 adverse events were reported in 141 of 191 patients (73.8\%). Three adverse events in 3 patients were judged to be related to CERA; these were 1 decreased appetite, 1 headache, and 1 pruritus. All were considered to be mild in intensity. Thirty eight SAE were reported in 30 patients. The most common SAE were infections such as sepsis, pneumonia, and wound infection. Sixteen events of uncontrolled high blood pressure which increased $\geq 30 \%$ of blood pressure at baseline and needed to add antihypertensive agents were reported in 15 patients (7.9\%). Two episodes of arteriovenous fistula complications and 1 episode of cerebral infarction developed in $2(1 \%)$ and 1 patient $(0.5 \%)$, respectively. Seven adverse events occurred in 5 patients $(2.6 \%)$ leading to withdrawal of these patients from the study. One patient received a transfusion for surgery due to a femur neck fracture and dropped out of the study. During the study period, 10 patients initiated dialysis ( 6 patients had haemodialysis and 4 patients had peritoneal dialysis) because of progression of CKD to end-stage renal disease. One patient $(0.5 \%)$ expired because of sepsis. There were no clinically relevant changes in the laboratory tests or vital signs during the study period.

\section{Discussion}

CERA has a prolonged half-life, which enables CKD patients to receive an ESA based on monthly visits to the outpatient nephrology clinic. Several studies have reported that conversion from ESA with shorter half-life to CERA successfully maintained a target $\mathrm{Hb}$ range in patients with CKD $[3,4,6]$. In this study, Hb levels were well maintained after switching from ESA with shorter half-life to CERA, as shown in previous studies. The conversion dose of CERA fell short of those suggested in the guidelines for switching from ESA with shorter half-life to CERA [3]. In this study, CERA dose adjustments were performed every 4 weeks. Decreases in the CERA dose occurred more frequently than increases, and the required dose of CERA was gradually reduced, which is consistent with previous study.

Although there is currently no standard definition of $\mathrm{Hb}$ overshoot, the mean amplitude of upward $\mathrm{Hb}$ excursions of $>3 \mathrm{~g} / \mathrm{dL}$ is commonly used based on clinical evidence [9]. Fishbane et al. reported that $>15 \%$ of patients who received recombinant human erythropoietin had $\mathrm{Hb}$ excursions $\geq 3 \mathrm{~g} / \mathrm{dL}$. In our study, we defined $\mathrm{Hb}$ overshoot as $\mathrm{Hb}$ excursions $\geq 3 \mathrm{~g} / \mathrm{dL}$ and analyzed patient groups according $\mathrm{Hb}$ overshoot. Hb overshoot presented in 14 patients $(9.7 \%)$, which is fewer than in the study by Fishbane et al. (> 15\%). Ziakka et al. reported 


\section{Kidney Blood Pressure Research}

Kidney Blood Press Res 2013;37:259-268

\begin{tabular}{l|l}
\hline DOI: 10.1159/000350151 & (C) 2013 S. Karger AG, Basel
\end{tabular}

Published onlıne: July 22, 2013

www.karger.com/kbr

Choi/Yang/Kim/Joo/Yoo/Lee/Lee/Moon/Shin/Huh/Kim/Park/Kim/Kim: Effect of Conversion from ESA with Shorter Half-Life to CERA in Pre-Dialysis CKD Patients

that the type of ESA affected the target $\mathrm{Hb}$ level. The percentage of Hb levels $>12.5 \mathrm{~g} / \mathrm{dL}$ was significantly greater when the patients were administered darbepoetin- $\alpha$ and CERA than administered epoetin- $\alpha$ and epoetin- $\beta$. They concluded that ESA with a longer half-life could cause more patients to overshoot the target Hb level [10]. In this study, since there was no data for the presence of overshoot before the ESA conversion, we were unable to compare the percentage of $\mathrm{Hb}$ overshoot between ESA with shorter half-life and CERA. Further studies may be needed to compare Hb overshoot between ESA with shorter half-life and CERA.

Erythropoietin could enhance endothelial activation and platelet reactivity, which may adversely affect patients at cardiovascular risk [8]. We measured biomarkers for endothelial and platelet reactivity to evaluate the effects of the type of erythropoietin. Soluble P-selectin, which is mostly derived from activated platelets, is used as a marker of platelet activation [11]. Increased platelet activation could promote a prothrombic effect [12]. There is much evidence that increased soluble P-selectin levels are associated with diseases such as ischemic stroke, atherosclerosis, and thromboembolic diseases $[13,14]$. In our study, P-selectin was slightly increased after switching from ESA with shorter half-life to CERA in the $\mathrm{Hb}$ overshoot group, although the difference was not statistically significant. Considering that treatment with ESA may enhance platelet aggregation by correcting anemia in dialysis patients [15], the changes in P-selectin in the Hb overshoot group may also be along the same lines, whereas P-selectin was significantly decreased in patients without Hb overshoot after switching from other ESAs to CERA. These data suggest that CERA may be more favorable than ESA with shorter half-life from the viewpoint of changes of platelet activation and prothrombotic probabilities.

E-selectin and VCAM are upregulated during inflammation and increase the adhesion of leukocytes to injured arterial endothelial cells, which is first step in subsequent atherosclerosis [16]. ESA increased E-selectin levels in healthy volunteers and haemodialysis patients, indicating substantial activation of endothelial cells $[8,17,18]$. Meanwhile, VCAM was variously affected by ESA. ESA treatment resulted in an increase of VCAM in healthy volunteers [8], whereas decrease in haemodialysis patients [18]. A cross-sectional study in non-dialysis CKD patients by Patel et al. showed that ESA status did not significantly affect serum VCAM levels [19]. In this study, VCAM was significantly increased with conversion to CERA, although E-selectin was not affected by switching the type of ESA. Currently, there is no data establishing that the type of ESA affects endothelial markers. It is uncertain whether or not the elevated VCAM levels observed in our study were associated with CERA. Further study regarding the effect of CERA on the endothelial microenvironment could provide more information on the effects ESAs on endothelial biomarkers.

Prohepcidin is precursor molecule of hepcidin, known as iron-regulatory hormone [20]. Detection of the biologically active form of hepcidin might have some limitations. Some evidence indicates that prohepcidin can be used as a reliable indicator of hepcidin levels [21, 22]. We measured prohepcidin levels in our study, but found no significant changes before and after conversion to CERA, whereas other biomarkers related to iron metabolism, such as serum ferritin and transferrin saturation, showed significant changes after switching. Several results showed that prohepcidin levels were not correlated with ferritin $[21,23]$. The patients in our study had very low CRP levels, therefore, it seems that other factors besides inflammation may modulate serum prohepcidin levels.

Adverse events considered by investigators to be related to treatment agent rarely occurred. Hypertension, known as the most common complication in CERA studies, occurred at lower rates in our study than in others [5-7]. Moreover, no SAE were assessed as being related to CERA.

\section{Conclusion}

Conversion from epoetin- $\alpha$, epoetin- $\beta$, or darbepoetin- $\alpha$ to subcutaneous once-monthly CERA in pre-dialysis CKD patients can efficaciously maintain $\mathrm{Hb}$ concentration, and the 


\section{Kidney \\ Blood Pressure Research}

Kidney Blood Press Res 2013;37:259-268

\begin{tabular}{l|l}
\hline DOI: 10.1159/000350151 & C 2013 S. Karger AG, Basel
\end{tabular}

Published onlıne: July 22, 2013

www.karger.com/kbr

Conversion from ESA with Shorter Half-Life to CERA in Pre-Dialysis CKD Patients

CERA dose requirements during the study period were significantly decreased compared with those at conversion. The conversion ratio may need to be adjusted when switching from ESA with shorter half-life to CERA. Of the serum biomarkers associated with coagulation and endothelial function, P-selectin was significantly decreased after conversion to CERA, suggesting that CERA may be more favorable than other ESAs from the viewpoint of changes of platelet activation and prothrombotic probabilities. VCAM was significantly increased after conversion compared with before conversion, however, E-selectin levels were not significantly altered. It is difficult to clearly describe the changes in endothelial biomarkers according to the ESA type. Further studies in larger sample populations with a longer followup period can more adequately explain changes in the microenvironment of biomarkers related to coagulation and endothelial function.

\section{Conflict of interest statement}

None declared.

\section{Acknowledgments}

This study was supported by Roche ${ }^{\circledR}$, Korea, and a grant from the Korean Healthcare Technology R\&D Project, Ministry for Health and Welfare, Republic of Korea (HI10C2020).

\section{References}

1 McMahon LP, Mason K, Skinner SL, Burge CM, Grigg LE, Becker GJ: Effects of haemoglobin normalization on quality of life and cardiovascular parameters in end-stage renal failure. Nephrol Dial Transplant 2000;15:1425-1430.

2 Ma JZ, Ebben J, Xia H, Collins AJ: Hematocrit level and associated mortality in hemodialysis patients. J Am Soc Nephrol 1999;10:610-619.

3 Minutolo R, Zamboli P, Chiodini P, Mascia S, Vitiello S, Stanzione G, Bertino V, Conte G, De Nicola L: Conversion of darbepoetin to low doses of cera maintains hemoglobin levels in non-dialysis chronic kidney disease patients. Blood Purif 2010;30:186-194.

4 Levin NW, Fishbane S, Canedo FV, Zeig S, Nassar GM, Moran JE, Villa G, Beyer U, Oguey D: Intravenous methoxy polyethylene glycol-epoetin beta for haemoglobin control in patients with chronic kidney disease who are on dialysis: A randomised non-inferiority trial (maxima). Lancet 2007;370:1415-1421.

$>5$ Carrera F, Lok CE, de Francisco A, Locatelli F, Mann JF, Canaud B, Kerr PG, Macdougall IC, Besarab A, Villa G, Kazes I, Van Vlem B, Jolly S, Beyer U, Dougherty FC: Maintenance treatment of renal anaemia in haemodialysis patients with methoxy polyethylene glycol-epoetin beta versus darbepoetin alfa administered monthly: A randomized comparative trial. Nephrol Dial Transplant 2010;25:4009-4017.

-6 Sulowicz W, Locatelli F, Ryckelynck JP, Balla J, Csiky B, Harris K, Ehrhard P, Beyer U: Once-monthly subcutaneous c.E.R.A. Maintains stable hemoglobin control in patients with chronic kidney disease on dialysis and converted directly from epoetin one to three times weekly. Clin J Am Soc Nephrol 2007;2:637646.

7 Topf JM: Cera: Third-generation erythropoiesis-stimulating agent. Expert Opin Pharmacother 2008;9:839849.

-8 Stohlawetz PJ, Dzirlo L, Hergovich N, Lackner E, Mensik C, Eichler HG, Kabrna E, Geissler K, Jilma B: Effects of erythropoietin on platelet reactivity and thrombopoiesis in humans. Blood 2000;95:2983-2989.

-9 Fishbane S, Berns JS: Hemoglobin cycling in hemodialysis patients treated with recombinant human erythropoietin. Kidney Int 2005;68:1337-1343. 


\section{Kidney \\ Blood Pressure Research}

Kidney Blood Press Res 2013;37:259-268

\begin{tabular}{l|l}
\hline DOI: $10.1159 / 000350151$ & (c) 2013 S. Karger AG, Basel
\end{tabular}

Publisned onilne: July ZZ, 2013

www.karger.com $/ \mathrm{kbr}$

Choi/Yang/Kim/Joo/Yoo/Lee/Lee/Moon/Shin/Huh/Kim/Park/Kim/Kim: Effect of Conversion from ESA with Shorter Half-Life to CERA in Pre-Dialysis CKD Patients

10 Ziakka S, Zagorianakos A, Koutsovasili A, Kaperonis N, Poulikakos D, Sgantzos A, Kolovos V, Ntatsis G, Papagalanis N: Efficacy of hemopoietic-stimulating factors in patients undergoing chronic hemodialysis. Ren Fail 2011;33:923-928.

11 Berger G, Hartwell DW, Wagner DD: P-selectin and platelet clearance. Blood 1998;92:4446-4452.

12 Dale GL, Alberio L: Is there a correlation between raised erythropoietin and thrombotic events in sicklecell anaemia? Lancet 1998;352:566-567.

-13 Frijns CJ, Kappelle LJ, van Gijn J, Nieuwenhuis HK, Sixma JJ, Fijnheer R: Soluble adhesion molecules reflect endothelial cell activation in ischemic stroke and in carotid atherosclerosis. Stroke 1997;28:2214-2218.

14 Chong BH, Murray B, Berndt MC, Dunlop LC, Brighton T, Chesterman CN: Plasma p-selectin is increased in thrombotic consumptive platelet disorders. Blood 1994;83:1535-1541.

15 Huraib S, Gader AM, al-Momen AK, Abu-Aisha H, al-Wakeel J, Memon NA: One-year experience of very low doses of subcutaneous erythropoietin in continuous ambulatory peritoneal dialysis and its effect on haemostasis. Haemostasis 1995;25:299-304.

16 Gogitidze Joy N, Hedrington MS, Briscoe VJ, Tate DB, Ertl AC, Davis SN: Effects of acute hypoglycemia on inflammatory and pro-atherothrombotic biomarkers in individuals with type 1 diabetes and healthy individuals. Diabetes Care 2010;33:1529-1535.

17 Heinisch BB, Vcelar B, Kapiotis S, Blann A, Wolzt M, Siller-Matula JM, Jilma B: The effect of erythropoietin on platelet and endothelial activation markers: A prospective trial in healthy volunteers. Platelets 2012;23:352-358.

18 Kahraman S, Yilmaz R, Kirkpantur A, Genctoy G, Arici M, Altun B, Erdem Y, Yasavul U, Turgan C: Impact of rhuepo therapy initiation on soluble adhesion molecule levels in haemodialysis patients. Nephrology (Carlton) 2005;10:264-269.

19 Patel TV, Mittal BV, Keithi-Reddy SR, Duffield JS, Singh AK: Endothelial activation markers in anemic nondialysis chronic kidney disease patients. Nephron Clin Pract 2008;110:c244-250.

20 Hentze MW, Muckenthaler MU, Galy B, Camaschella C: Two to tango: Regulation of mammalian iron metabolism. Cell 2010;142:24-38.

21 Costa E, Pereira BJ, Rocha-Pereira P, Rocha S, Reis F, Castro E, Teixeira F, Miranda V, do Sameiro Faria M, Loureiro A, Quintanilha A, Belo L, Santos-Silva A: Role of prohepcidin, inflammatory markers and iron status in resistance to rhepo therapy in hemodialysis patients. Am J Nephrol 2008;28:677-683.

22 Malyszko J, Malyszko JS, Pawlak K, Mysliwiec M: Hepcidin, iron status, and renal function in chronic renal failure, kidney transplantation, and hemodialysis. Am J Hematol 2006;81:832-837.

$\checkmark 23$ Taes YE, Wuyts B, Boelaert JR, De Vriese AS, Delanghe JR: Prohepcidin accumulates in renal insufficiency. Clin Chem Lab Med 2004;42:387-389. 